\title{
CHARACTERIZATION OF GLUED LAMINATED PANELS PRODUCED WITH STRIPS OF BAMBOO (Guadua magna) NATIVE FROM THE BRAZILIAN CERRADO
}

Keywords:

Phenolic resin

Taquaruçu

PVA

properties

Histórico:

Recebido 18/09/2014 Aceito 15/11/2015

Palavras chave: Resina fenólica Taquaruçu PVA

Propriedades

Correspondência: divino.teixeira@florestal.gov.br
ABSTRACT: Panels were produced with strips of bamboo (Guadua magna) in layers crossed at angles of $90^{\circ}$ and bonded with phenol-formaldehyde or PVA based resin, glued in three and five plies. The panels were tested and the physical and mechanical properties determined. The tests were primarily related to the commercial adhesives used as well as the number of layers of bamboo used. The density ranged from 0.690 to $0.768 \mathrm{~g} \cdot \mathrm{cm}^{-3}$. Panels bonded with PVA resin showed low mechanical strength, with MOR between 6.7 and 7.8 $\mathrm{MPa}$. Those bonded with phenol-formaldehyde adhesive showed high strength, with modulus of rupture (MOR) ranging from 55.5 to $87.0 \mathrm{MPa}$, which is excellent for boards similar to wood-based panels. Panels with phenolic resin also had reduced thickness swelling, up to $8.4 \%$. The panels made with three layers showed higher resistance to bending than those made with five layers.

\section{CARACTERIZAÇÃO DE PAINÉIS LAMINADOS COLADOS PRODUZIDOS COM TALISCAS DE BAMBU (Guadua magna) NATIVO DO CERRADO}

RESUMO: Painéis foram produzidos com taliscas de bambu (Guadua magna) montados em três ou cinco camadas cruzadas entre si em ângulo de $90^{\circ}$ e coladas com resina à base de fenol-formaldeído ou PVA. Os painéis foram testados e as propriedades físicas e mecânicas determinadas. Os testes foram quanto aos adesivos comerciais usados, bem como a quantidade de camadas dos painéis. A densidade variou entre 0,690 e $0,768 \mathrm{~g} \cdot \mathrm{cm}^{-3}$. Painéis colados com resina PVA mostraram baixa resistência mecânica, apresentando MOR entre 6,7 e 7,8 MPa. Os colados com resina fenol-formaldeído foram mais resistentes, com módulo de ruptura (MOR) entre 55,5 e 87,0 MPa, excelente para painéis similares à base de madeira. Painéis com resina fenólica apresentaram também reduzido inchamento em espessura, até $8,4 \%$. Os painéis produzidos em três camadas apresentaram resistência maior à flexão que os com cinco camadas. 


\section{INTRODUCTION}

Bamboo is a monocotyledon plant of the grass family Poaceae subfamily Bambuseae, producer of flowers and seeds, and having axial fibrous and vascular systems (ALMEIDA, 2004).

The aerial part of bamboo corresponds to the tree trunk and is called stem, and is basically a straight vertical piece. The anatomical structure of the bamboo stem is composed of nodes and walls (or internodes), with cells and fibers oriented axially. This structure influences directly on the physical and mechanical properties. The wall of the stem possesses two distinct transversal parts: an outer, tough and waterproof layer formed by an epidermal cell; and an inner part, consisting of parenchyma tissue, where capillary vessels or sap conductors, deposits of starch and fibers are the main components. The outer layer of the bamboo stem contains high proportions of silicate (about 4\%), being resistant to insect attacks. The bamboo wall is composed of $50 \%$ of parenchyma, $40 \%$ of fiber and $10 \%$ of vessels. The nodes have from $40 \%$ to $50 \%$ of fibers (DUNKELBERG, 1985).

The bamboos of the genus Guadua have a crucial importance in the economy of Ecuador and Colombia, and as construction material it has species with high strength, such as Guadua angustifolia. In Brazil there are many natural Guadua inhabited forests, in the Amazon and in vast areas of the Brazilian territory, from south to north. The species $G$. magna was recently described by Filgueiras and Londoño (2006) as Guadua magna Londoño \& Filg.

Due to the good physical and mechanical properties of bamboo, as well as the peculiar geometrical shape, low cost and ease to be obtained, the plant is widely used as construction material in various countries in which it grows abundantly, especially in tropical and subtropical areas of Asia and in some Latin American countries. Bamboo has high impact resistance and flexural strength, in part due to the high strength of its fibers in tension (BERALDO; RIVERO, 2003; SILVA, 2004). Recent studies demonstrate the technical feasibility of using bamboo for production of composites panels (ARRUDA, 20II; ARAÚJO, 20II).

Brazil has presented a very strong demand in the construction and residential renovations area, furniture industry, packaging and others. This fact combined with the decreasing supply estimated for timber from native forests in the near future, either from tropical and planted areas, demands for the search of lignocellulosic materials that can furnish the forest based industry in the coming decades (ABIMCI, 2009; IWAKIRI et al., 2005 ; IWAKIRI et al., 2009).

Bamboo, when compared to timber and in particular to planted forests, has many advantages such as rapid growth, high productivity, fast maturation, excellent properties and versatility of uses. The characteristics of silviculture, growth and mechanical resistance of the bamboo, opens the possibility to introduce this material for the manufacture of laminates (MOIZÉS, 2007; STAMM, 2002). As an alternative, the cultivation of bamboo can help avoid the cutting of woods under pressure used for these purposes.

Recently the Legislative Law 12484 was approved in Congress in 2011, which provides for a national policy to encourage the sustainable management and cultivation of bamboo. The law provides for research and technological development and applications of the products and byproducts of bamboo (REPÚBLICA FEDERATIVA DO BRASIL, 20I I).

This study aimed to determine the physical and mechanical properties of laminated panels produced with strips of bamboo Guadua magna bonded with two types of glues.

\section{MATERIAL AND METHODS}

\section{Bamboo species}

The used bamboo species Guadua magna is popularly known as "Taquaruçu", and was collected in the municipality of Santa Teresa, in the state of Goiás (Center region of Brazil) in a clump with 4 years of age.

\section{Preparation of the bamboo strips}

The stems were cut with a chainsaw, and then transformed into pieces covering the entire wall thickness, using a bandsaw. The bamboo diaphragms were also removed using the bandsaw. The pieces were then planned in the inner side without bark and the width adjusted between 20 and $30 \mathrm{~mm}$ (Figure I).

Next, strips were removed from each piece on a router, equipped with a circular saw. From each piece an average of two strips were cut. The final strips exhibited between 20 and $30 \mathrm{~mm}$ in width and between 500 and $600 \mathrm{~mm}$ in length. The thickness of the strips obtained varied from 1.0 and $2.4 \mathrm{~mm}$. 


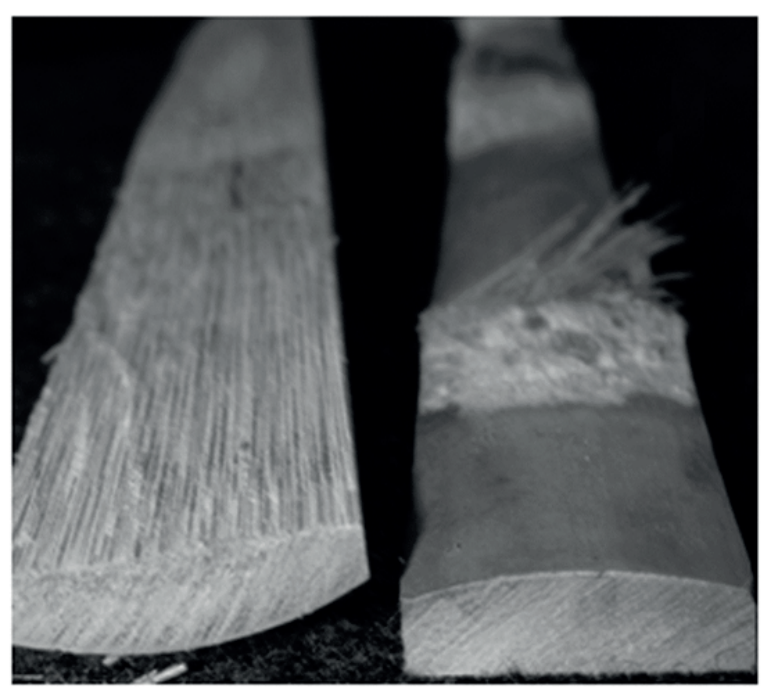

Figure I Planning of bamboo.

Figura I Aplainamento do bambu.

\section{Manufacture of the laminated panels}

The laminated panels of Guadua magna were produced from bamboo strips, glued laterally together on an uneven number of layers arranged adjacent and perpendicular to each other, and having two outer layers (face and backface) composed of one veneer of wood of ipê champagne (Dipteryx odorata) as decorative purposes as shown in Figure 2. A total of nine laminated panels measuring $300 \times 300 \mathrm{~mm}$ were produced as follows: three of them with three inner layers of Taquaruçu and having a final thickness of 6.0 $\mathrm{mm}$ and three with five internal and two external layers presenting a final thickness between $9.0 \mathrm{~mm}$ and 10.0 $\mathrm{mm}$, all bonded with the commercial phenolic resin type Cascophen HL-2080. The three other panels were made the same way as mentioned before, having three inner layers of bamboo and bonded with the PVA type adhesive Rhodopas (Table I).

Table I Experimental design of the study.

Tabela I Delineamento experimental do estudo.

\begin{tabular}{cccc}
\hline $\begin{array}{c}\text { Treatment } \\
\text { (Panels) }\end{array}$ & $\begin{array}{c}\text { Internal layers } \\
\text { of bamboo }\end{array}$ & Adhesive used & $\begin{array}{c}\text { Panel thickness } \\
(\mathrm{mm})\end{array}$ \\
\hline PVA-3L & 3 & PVA & 8.5 \\
PF-3L & 3 & $\begin{array}{c}\text { Phenol- } \\
\text { formaldehyde } \\
\text { Phenol- }\end{array}$ & 6.0 \\
PF -5L & 5 & \begin{tabular}{c} 
formaldehyde \\
\hline
\end{tabular} \\
\hline
\end{tabular}

The pressing was performed in a hydraulic press at a pressure of $0.76 \mathrm{MPa}$ and a temperature of $140^{\circ} \mathrm{C}$ for 8 minutes for panels glued with phenolic resin Cascophen HL-2080. The panels bonded with the PVA glue were pressed at the same pressure at room temperature. After pressing, the panels were stored for 24 hours, then squared and taken to a conditioning room with controlled temperature of $20^{\circ} \mathrm{C}$ and $60 \%$ of relative humidity to reach equilibrium moisture content.

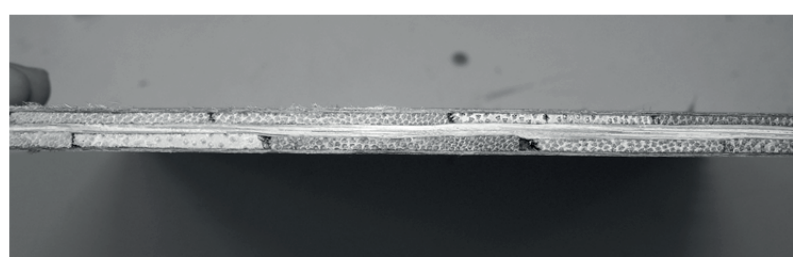

Figure 2 Laminated panel with three layers of bamboo in the core and two wood veneer faces.

Figura 2 Painel laminado com três camadas de bambu no miolo e duas lâminas de madeira nas faces.

\section{Adhesives}

Two commercial adhesives were used and applied with a foam paint roller. One of these adhesives is suitable for hot pressing and moisture resistant and the other for cold pressing and not moisture resistant. The preparation of each adhesive followed the recommendation of the manufacturer.

- Phenol-Formaldehyde (Cascophen HL-2080) - PF: phenolic resin normally applied to plywood for external use. The formulation of the glue used was 100 parts of resin, 10 parts of water to adjust the viscosity and 10 parts of wheat flour, as an extender, both mixed to the resin to obtain a homogeneous mixture. The amount of glue used was $360 \mathrm{~g} \cdot \mathrm{m}^{-2}$. The viscosity of the adhesive was adjusted to $590 \mathrm{cPs}$.

- PVA (Rhodopas A503): resin based on polyvinyl acetate (PVA) applied for internal use. The amount of adhesive used was $360 \mathrm{~g} \cdot \mathrm{m}^{-2}$.

\section{Panels testing}

The following properties were determined:

- Bending strength: Modulus of Rupture (MOR) and modulus of elasticity (MOE) in accordance with EN 310 (1993). Each panel was cut in four samples of $140 \times 50$ $\mathrm{mm}$ in the parallel direction to the fibers and three in the perpendicular direction, a total of 21 specimens per treatment, or type of panel, and grand total of 63. 
- Specific mass (M.E.A.): determined in the static bending specimens.

- Water absorption and thickness swelling: according to ASTM DI 037 (1999). Seven specimens of 50 $x 50 \mathrm{~mm}$ were cut from each panel, totaling 21 specimens per treatment, or type of panel, and 63 in the grand total.

- Janka hardness: according to ASTM DI037 (1999). Seven specimens were cut from each panel bonded with PF resin and six from each PVA bonded panel. The overall total tested was 60 specimens.

The data analysis was performed with the aid of SPSS 13.0 software. The experiment was set up as a randomized experimental design with three treatments: two layers ( 3 and 5 ply) assigned to the PF resin and one layer ( 3 ply) assigned to the PVA. An analysis of variance with $5 \%$ significant level was used to compare results and the Tukey test for means comparison.

\section{RESULTS AND DISCUSSION}

The $G$. magna bamboo culms used in this study have the dimensions shown in Table 2.

Table 2 Average dimensions of $G$. magna bamboo culms. Tabela 2 Dimensões médias dos colmos de bamboo G. magna.

\begin{tabular}{ccccccc}
\hline $\begin{array}{c}\text { Length } \\
(\mathrm{mm})\end{array}$ & \multicolumn{3}{c}{$\varnothing$ top $^{\prime}(\mathrm{mm})$} & \multicolumn{2}{c}{$\varnothing$ bottom $^{2}(\mathrm{~mm})$} \\
\cline { 2 - 7 } & $\varnothing$ & $\mathrm{WT}^{3}$ & Lumen & $\varnothing$ & $\mathrm{WT}$ & Lumen \\
\hline 2197 & 123.12 & 22.90 & 82.15 & 106.35 & 17.83 & 73.23
\end{tabular}

(I) Larger diameter of the culms; (2) Smaller diameter of the culms; (3) Wall thickness.

The overall results of the $G$. magna laminated panels are shown in Table 3.

\section{Physical Characterization}

\section{The apparent specific mass (M.E.A.)}

The density at $12 \%$ moisture content (M.E.A.) of the panels ranged from 0.69 to $0.77 \mathrm{~g} \cdot \mathrm{cm}^{-3}$. The Tukey test showed a significant difference between the panels produced with PVA glue $\left(0.77 \mathrm{~g} \cdot \mathrm{cm}^{-3}\right)$ and with the phenolic adhesive. To eliminate the effect of M.E.A., a correlation test was performed correlating this property with others studied. Only MOR significantly correlated with M.E.A.

The moisture content was $6.8 \%$ with PVA glue for the laminated panels and $9.8 \%$ and $10.6 \%$ for $\mathrm{PF}$ with three and five layers, respectively.

\section{Water absorption (WA) and thickness swelling (TS)}

The Tukey test for the panels' water absorption showed that this property was linear along all treatments with no significant difference. The absorption of the panels varied from $46 \%$ to $46.9 \%$. There was no influence of adhesive type or number of layers in the water absorption.

Regarding TS, the adhesives influenced this property significantly. Laminated panels bonded with PVA were less stable dimensionally, with an average of 14.4\%. Panels bonded with phenolic resin were not significantly different and more stable with average TS ranging from $8.0 \%$ to $8.4 \%$. Marton (2008) obtained TS and WA values of $33.7 \%$ and $6 \%$, respectively.

Table 3 Physical and mechanical properties of $G$. magna bamboo laminated panels.

Tabela 3 Propriedades físicas e mecânicas dos painéis laminados de bambu G. magna.

\begin{tabular}{|c|c|c|c|c|c|c|c|c|}
\hline \multirow{3}{*}{ Treatment } & \multicolumn{8}{|c|}{ Properties } \\
\hline & \multicolumn{2}{|c|}{ MOR (MPa) I } & \multicolumn{2}{|c|}{ MOE (MPa) } & \multirow{2}{*}{$\begin{array}{l}\text { WA } \\
(\%)\end{array}$} & \multirow{2}{*}{$\begin{array}{l}\text { TS } \\
(\%)\end{array}$} & \multirow{2}{*}{$\begin{array}{c}\text { Janka } \\
\text { Hardness } \\
(\mathrm{N})\end{array}$} & \multirow{2}{*}{$\begin{array}{l}\text { M.E.A. } \\
\left(\mathrm{g} \cdot \mathrm{cm}^{-3}\right)\end{array}$} \\
\hline & $(/ /)^{2}$ & $(\perp)$ & $(/ /)$ & $(\perp)$ & & & & \\
\hline \multirow[t]{2}{*}{ PVA-3L ${ }^{3}$} & $6.7^{A}$ & $7.8^{A}$ & $440^{\mathrm{A}}$ & $400^{A}$ & $46.0^{A}$ & $14.4^{\mathrm{B}}$ & $614^{A}$ & $0.77^{\mathrm{A}}$ \\
\hline & $(1.96)$ & (2.9) & $(161)$ & $(107)$ & $(7.1)$ & $(4.8)$ & $(109)$ & $(0.07)$ \\
\hline \multirow[t]{2}{*}{ PF-3L } & $81.6^{c}$ & $69.8^{\mathrm{B}}$ & $8123^{c}$ & $5198^{c}$ & $46.9^{A}$ & $8.4^{\mathrm{A}}$ & $564^{A}$ & $0.73^{B}$ \\
\hline & $(18.7)$ & $(I I .5)$ & $(1749)$ & $(1024)$ & $(3.9)$ & $(1.6)$ & $(953)$ & $(0.05)$ \\
\hline \multirow[t]{2}{*}{$P F-5 L$} & $55.5^{B}$ & $65.3^{B}$ & $4438^{B}$ & $4202^{B}$ & $46.3^{A}$ & $8.3^{A}$ & $630^{A}$ & $0.69^{B}$ \\
\hline & $(11.8)$ & $(12.1)$ & (799) & $(1135)$ & $(7.0)$ & $(4.0)$ & (95) & $(0.03)$ \\
\hline $\mathrm{ABIMCl}{ }^{4}$ & 48.8 & 22.0 & 8.377 & 2.228 & - & - & - & - \\
\hline
\end{tabular}

Note: (I) I $\mathrm{MPa}=10.197 \mathrm{~kg} \cdot \mathrm{cm}^{-2} ; \mathrm{MOR} / \mathrm{MOE}=$ modulus of rupture and elasticity; WA = water absorption; TS = thickness swelling; M.E.A. = density at I $2 \%$ moisture content; (2) // = In the parallel direction to the fibers of the external strips of bamboo panels; $\perp=$ In the perpendicular direction to the fibers of the external strips of bamboo panels; (3) PVA-3L: PVA based panels with three layers of bamboo strips; PF-3L: Phenol-Formaldehyde panels with three layers of bamboo strips; PF-5L: Phenol-Formaldehyde panels with five layers of bamboo strips.; (4) ABIMCI (2002): Average values for 9 mm-thick tropical pine plywood with 5 layers. 


\section{Mechanical properties}

\section{Static Bending}

The static bending was conducted in accordance to EN 310 (1996) standard. The specimens showed Modulus of Rupture (MOR) and modulus of elasticity (MOE) with large difference between the two types of adhesives. Panels bonded with PVA presented low resistance in both test directions, with average MOR of 6.7 and $7.8 \mathrm{MPa}$ in the parallel and perpendicular directions, respectively. Regarding $M O E$, the values obtained were 440 to $400 \mathrm{MPa}$, respectively. On the other hand, panels bonded with PF adhesive showed high resistance ranging from 55.5 to $81.6 \mathrm{MPa}$ for MOR and 4,202 to 8, I $23 \mathrm{MPa}$ for MOE. As for the test of fibers direction there is a slight tendency of higher strength in the parallel direction. The technical specification of $\mathrm{ABIMCl}$ (2002) set requirements for $12 \mathrm{~mm}$-thick commercial plywood made with Pinus taeda and bonded with phenol-formaldehyde resin, used for structural purposes, to have reference values of 6,899 $\mathrm{MPa}$ for MOE and 38. I MPa for MOR. Thus, as comparison, the values of these properties for bamboo laminated panels overcame those of the standard.

Iwakiri et al. (2009) produced PF bonded plywood from six species of tropical pine ( $P$. taeda, $P$. chiapensis, $P$. caribaea var. hondurensis, $P$. maximinoi, $P$. oocarpa and $P$. tecunumannii) and obtained an average of 7,843 MPa for MOE, for panels with $P$. caribaea strips. Five-ply plywood with five species of tropical pine showed average MOR ranging from 51.2 to $81.5 \mathrm{MPa}$, near to those obtained in this study for bamboo.

Prata (2006) obtained for 12 mm-thick commercial pine plywood bonded with PF resin average values of 6,270 and $25.5 \mathrm{MPa}$, respectively for MOE and MOR, lower than those obtained with bamboo.

Marton (2008) obtained values of 2.46 and 3.82 MPa for MOR parallel and perpendicular to grain, respectively, over five-ply plywood from $D$. giganteus bamboo bonded with PF (same one used in this project) with M.E.A. of $0.925 \mathrm{~g} \cdot \mathrm{cm}^{-3}$. Palma et al. (20I2) produced Hevea brasiliensis plywood with veneers classified by stress wave and obtained MOR ranging from 43.06 to 57. I I MPa and MOE from 5,227 to 6,772 MPa.

The laminated panels assembled with core of five and three layers of bamboo glued with PF met the requirements for the ABNT NBR-9532 (1986) for plywood used as concrete forms, which minimum MOE is $4,000 \mathrm{MPa}$.
Analyzing separately the type of adhesive, the results showed that the PVA-based adhesive is much less resistant than the PF bonded panels. Analyzing only the PF bonded panels and number of layers, the arrangement with three layers showed better results than the five-layer. These results are consistent with the ABIMCI Catalogue (2007), where I $2 \mathrm{~mm}$-thick pinus and tropical plywood with 5 layers have higher MOR than I8mm-thick plywood with 7 layers.

\section{Janka Hardness}

The Janka hardness test showed that both type of adhesive and number of layers did not influence the results, with no significant difference between the different treatments. The Janka hardness ranged from 564 to $630 \mathrm{~N}$

\section{CONCLUSION}

The results indicate that the bamboo species G. magna performs best when bonded with the waterproof phenol-formaldehyde resin for thickness swelling and static bending, which is recommended for outdoor use in construction.

The three layer-laminated panels bonded with FF resin presented highest resistance (MOR) and stiffness (MOE) of static bending in the parallel direction. No difference for the other properties was detected regarding the number of layers.

The PVA based adhesive laminated panels can be used for interior applications (IR) in places protected from direct contact to water or high relative humidity, while the PF adhesive can be used for intermediate (IM) or exterior (EX) applications. G. magna bamboo was revealed to be technically feasible for using in laminated panels.

\section{REFERENCES}

ALMEIDA, J. G. Caracterização geométrica de bambus para construção e manufatura de objetos: análise comparativa da Guadua weberbaueri e do Phyllostachys bambusoides. Brasil Florestal, 2004; (80):5 I-65.

AMERICAN SOCIETY FOR TESTING AND MATERIALS ASTM. ASTM D 1037. Standard test methods for evaluating properties of wood-base fiber and particle panel materials. Annual Book of ASTM Standards, Philadelphia. 1999. 
ARAÚJO, P.C.; ARRUDA, L.M.; DEL MENEZZI, C. H. S.; TEIXEIRA, D. E.; SOUZA, M. R. Lignocellulosic Composites from Brazilian giant bamboo (Guadua magna). Part 2: Properties of cement and gypsum bonded particleboards. Maderas. Ciencia y Tecnología, 20I I; (I3): I-5.

ARRUDA, L. M.; DEL MENEZZI, C. H. S.; TEIXEIRA, D. E.; ARAÚJO, P. C. Lignocellulosic composites from Brazilian giant bamboo (Guadua magna) Part I: Properties of resin bonded particleboards. Maderas. Ciencia y Tecnología, 20II; (I3):49-58.

ASSOCIAÇÃO BRASILEIRA DA INDÚSTRIA DA MADEIRA PROCESSADA MECANICAMENTE - ABIMCI. Estudo setorial 2009 ano base 2008 - Indústria de Madeira Processada Mecanicamente. Curitiba, 2009. 45p.

ASSOCIAÇÃO BRASILEIRA DA INDÚSTRIA DA MADEIRA PROCESSADA MECANICAMENTE - ABIMCI. Compensado de Pinus: Catálogo Técnico - No $\mathbf{I}$. Curitiba, 2002. 22p.

ASSOCIAÇÃO BRASILEIRA DA INDÚSTRIA DA MADEIRA PROCESSADA MECANICAMENTE-ABIMCI.

Compensado de madeira tropical: Catálogo Técnico. Disponível em: <www.abimci.com.br/wp-content/ uploads/2014/02/Cata logo_Tecnico_Compensado_Tropical. pdf $>$. Curitiba, 2007. 2p. Acesso em 23/04/20I5.

ASSOCIAÇÃO BRASILEIRA DA INDÚSTRIA DA MADEIRA PROCESSADA MECANICAMENTE - ABIMCI. Compensado de Pinus: Catálogo Técnico. 2007. 2p. Disponível em: <www.abimci.com.br/wpcontent/ uploads/2014/02/Catalogo_Tecnico_Compensado_Pinus. pdf $>$. Acesso em 23/04/20I5.

ASSOCIAÇÃO BRASILEIRA DE NORMAS TÉCNICAS. NBR9484: Compensado - Determinação do teor de umidade, 1996.

ASSOCIAÇÃO BRASILEIRA DE NORMAS TÉCNICAS. NBR9532: Chapas de madeira compensada - Especificação. 1986.

BERALDO, A. L.; RIVERO, L. A. Bambu Laminado Colado (BLC). Floresta e Ambiente, 2003; 10(2):36-46.

DUNKELBERG, K. Bamboo as a Building Material. Stuttgard: Institute for Lightweight Structures (IL), 1985.

EUROPEAN COMMITTEE FOR STANDARDIZATION. EN 3 10: 1993: Wood based panels - Determination of modulus of elasticity and modulus of rupture in static bending. Brussels. 1993.
FILGUEIRAS, T. S.; LONDOÑO, X. A. Giant new Guadua (Poaceae: Bambusoideae) from Central Brazil. In: Proceedings of Ist National Seminar on Development of the Brazilian Bamboo Research Network, Brasília, Brazil, pp. 27 - 33. 2006.

IWAKIRI, S.; MATOS, J. L. M.; LIMA, A. J. M.; FERREIRA, É. da S.; BATISTA, D. C.; ROMÃO, S. A. A. Produção de painéis compensados de pinus tropicais colados com resina fenol-formaldeído. Floresta, 2009; 39(3):669-673. Curitiba, PR.

IWAKIRI, S. Painéis de Madeira Reconstituída. Departamento de Engenharia e Tecnologia Florestal UFPR. 2005.

MARTON, G. L. Produção de compensados de bambu (Dendrocalamus giganteus) utilizando adesivos à base de fenol e uréia [monografia]. Seropédica, RJ: Engenharia Florestal, Instituto de Florestas, Universidade Federal Rural do Rio de Janeiro; 2008. $21 \mathrm{p}$.

MOIZÉS, F. A. Painéis de Bambu, uso e aplicações: uma experiência didática nos cursos de Design em Bauru, São Paulo [dissertação]. Bauru, SP: Faculdade de Arquitetura, Artes e Comunicação, Universidade Estadual Paulista; 2007.

PALMA, H. A. L.; ESCOBAR, J. F.; BALLARIN, A. W.; LEONELLO, E. C. Influência da qualidade das lâminas no desempenho mecânico à flexão de painéis compensados de Hevea brasiliensis. Floresta e Ambiente, 2012; 19(2):133-140.

PRATA, J. G. Desempenho de um sistema de qualidade em uma fábrica de painéis compensados [dissertação]. Curitiba, PR: Ciências Florestais, Universidade Federal do Paraná: 2006.106p.

REPUBLICA FEDERATIVA DO BRASIL. Lei n. 12.484 , de 8 de Setembro de 20 I I. Dispõe sobre a Política Nacional de Incentivo ao Manejo Sustentado e ao Cultivo do Bambu e dá outras providências. Diário Oficial da República Federativa do Brasil, Brasília, DF (201 I set. 9); Sec. I: I-2.

SILVA, F. A.; GHAVAMI, K.; D'ALMEIDA, J. R. M. Comportamento ao impacto de laminados de bambu. In: IX Encontro Brasileiro em Madeira e em Estrutura de Madeira. Cuiabá, julho 2004.

STAMM, J. Proyecto latas y laminados de Guadua - informe final. Proyecto U.T.P.-GTZ. Pereira, I4p. 2002. 